\title{
Role of parenting styles in internalizing, externalizing, and adjustment problems in children
}

\author{
Jaime Humberto Moreno Méndez, ${ }^{1}$ José Pedro Espada Sánchez, ${ }^{1}$ María Inmaculada Gómez Becerra²
}

Universidad Miguel Hernández de Elche, España

2 Universidad de Almería, España.

\section{Correspondence:}

Jaime Humberto Moreno Méndez Universidad Miguel Hernández de Elche, España.

Avinguda de la Universitat d'Elx, s/n, 03202 Elche, Alicante, España.

Email: jaimehm@yahoo.com

Received: 31 March 2019

Accepted: 5 December 2019

Citation:

Moreno Méndez, J. H., Espada Sánchez, J. P., \& Gómez Becerra, M. I. (2020). Role of parenting styles in internalizing, externalizing, and adjustment problems in children. Salud Mental, 43(2), 73-84.

DOI: $10.17711 /$ SM.0185-3325.2020.011

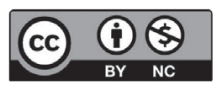

\begin{abstract}
Introduction. Different studies have reported the relationship of parenting styles with adjustment problems in children. However, it has not been specified which aspects of parenting styles play a central role in the manifestation of such psychological problems. Objective. To increase the knowledge about the role of which parental educational styles are associated with internalizing, externalizing, and adjustment problems in Colombian children. Method. Through structural equations, the fit of the proposed model was verified. Participants were 422 parents and children aged between 8 and 12 years, enrolled in public schools in Bogota, Colombia. The Parental Educational Styles Questionnaire, the Child Behavior Checklist, and the Parent Format and Self-assessment Multifactorial Adjustment test were applied. Results. Family dynamics and parental practices have effects on internalizing, externalizing, and general maladjustment problems. Parental roles and practices show indirect effects on general maladjustment through externalizing problems. Discussion and conclusion. The models tested show that conflicts at home, parental overload, impulsivity, permissive, ambiguous/non-consistent styles, and dysfunctional reaction to disobedience play a role in the manifestation of internalizing, externalizing, and adjustment problems in children.
\end{abstract}

Keywords: Adjustment, child, externalizing problems, internalizing problems, parenting.

\section{RESUMEN}

Introducción. Diferentes estudios han reportado la relación de los estilos de crianza con problemas de adaptación en niños. Sin embargo, no se ha especificado qué aspectos de los estilos de crianza desempeñan un papel central en la manifestación de tales problemas psicológicos. Objetivo. Incrementar el conocimiento acerca del papel de qué estilos educativos parentales se asocian con los problemas internalizantes, externalizantes y de adaptación en niños colombianos. Método. Por medio de ecuaciones estructurales se probó el ajuste al modelo. Los participantes fueron 422 padres con hijos de entre 8 y 12 años, matriculados en colegios públicos en Bogotá, Colombia. Se aplicó el Cuestionario de Estilos Educativos de los Padres, la Lista de Chequeo del Comportamiento Infantil, el Formato para padres y el Test Autoevaluativo Multifactorial de adaptación. Resultados. Las dinámicas familiares y las prácticas parentales tienen efectos sobre los problemas internalizantes, externalizantes y de adaptación general. Los roles y las prácticas parentales muestran efectos indirectos sobre la desadaptación general a través de problemas externalizantes. Discusión y conclusión. Los modelos probados muestran que los conflictos en el hogar, la sobrecarga de los padres, la impulsividad, los estilos permisivos, ambiguos/no consistentes y la reacción disfuncional a la desobediencia desempeñan un papel en la manifestación de los problemas internalizantes, externalizantes y de adaptación en los niños.

Palabras clave: Adaptación, niño, problemas externalizantes, problemas internalizantes, crianza de los hijos. 


\section{INTRODUCTION}

Parenting styles play a fundamental role in the mental health of children because with them, parents set limits and rules as well as an affective exchange with their children. Previous studies documented the significant interactive effects between severe discipline on the part of parents and such problems in children (Chen et al., 2015; Hser et al., 2015; Leathers, Spielfogel, Geiger, Barnett, \& Voort, 2019; McCullough \& Shaffer, 2014; Porche, Costello, \& Rosen-Reynoso, 2016). Furthermore, Pearl, French, Dumas, Moreland, and Prinz (2014) concluded that paternal quality predicts child externalization, and they suggest continuing with research that accounts for the implications of parenting on children's adjustment.

Other psychological problems that affect the adaptation of children are internalizing behaviors. Voltas, Hernández-Martínez, Arija, and Canals (2016) report that children with depression and anxiety show a higher deterioration in their activities at home, school, and in their relationships with their peers.

In Colombia the range of highest prevalence of clinical problems is 8 to 12 years, with the presence of at least one symptom of internalizing and externalizing type being reported in $44.7 \%$ of the cases. It is a figure close to half the total child population, which makes it a public health problem and merits studying parental variables associated with the development of these problems in children in this age range (Ministerio de Salud \& Colciencias, 2015).

As for the role of cohesion and family communication, Jouriles, Rosenfield, McDonald, and Mueller (2014), as well as Zuñeda, Llamazares, Marañón, and Vázquez (2016), found that when there are problems in family dynamics, there is a lower capacity to adjust to vital family events, as well as aggressive behavior in children. As for shared leisure, Baker (2014) found associations with school adjustment in children, and Offer (2014) did the same with higher positive affect on children. In the opposite sense, externalizing problems in children were associated with a diminished dedication of the mothers to their children (Chisholm, Gonzalez, \& Atkinson, 2014) and with low satisfaction and commitment of the raising by both parents (Raya, Pino, \& Herruzo, 2009).

On support relationships between family and school, Barg (2019) and García-Bacete (2003) emphasize that parents who value their role in the education of their children improve communication with them. In relation to parental overload, lack of parental support hinders the development of pro-social skills and emotional regulation in children (Murry, McNair, Myers, Chen, \& Brody, 2014).

On the other hand, difficulties to resist and/or control impulses hinder the processes necessary for the emotional regulation and for adjustment to the environment. In this sense, impulsivity has been linked to diminished self-control (Ham- ilton, Sinha, \& Potenza, 2014), and provides a risk of maltreatment of children (Henschel, de Bruin, \& Möhler, 2014).

The emotional expression of parents in the family ambit is important because it is the primary context in which children gain an understanding of the emotions of others (Bariola, Gullone, \& Hughes, 2011). Parents who are less accepting of their children's emotions generate adjustment problems for them (Cumsille, Martínez, Rodríguez, \& Darling, 2015; Mirabile, 2014; Ramírez-GarcíaLuna, Araiza-Alba, Martínez-Aguiñaga, Rojas-Calderón, \& Pérez-Betancourt, 2016).

In different studies it has been reported that the use of a democratic upbringing style has positive emotional and behavioral effects on children (Osorio \& González-Cámara, 2016; Rankin Williams et al., 2009; Uji, Sakamoto, Adachi, \& Kitamura, 2014). Also, said educational style is a safe-conduct for the education and development of socially accepted behaviors (Jabagchourian, Sorkhabi, Quach, \& Strage, 2014).

Otherwise, the educational permissive style has been associated with internalizing problems in children (Rankin Williams et al., 2009), with difficulties in their school adjustment process (Moreno, Echavarría, Pardo, \& Quiñones, 2014), and impairments in children's mental health (Barton \& Hirsch, 2016; Uji et al., 2014).

Regarding the ambiguous/non-consistent style, Hernández, Gómez, Martin, and González (2008) found that frequent punishment or allowing children to perform activities that are normally prohibited are risk factors for behavioral problems (Jiménez-Barbero, Ruiz-Hernández, Velandrino-Nicolás, \& Llor-Zaragoza, 2016).

The educational authoritarian style is related to externalizing and internalizing problems in children (Leiner et al., 2015; Rescorla, Althoff, Ivanova, \& Achenbach, 2019; Stoltz et al., 2013) and poor affiliation with parental values (Barry, Frick, \& Grafeman, 2008). Laukkanen, Ojansuu, Tolvanen, Alatupa, and Aunola (2014) found that the mother's feelings of inadequacy may lead her to use psychological control with the child, typical of an authoritarian style. Such a style worsens the mental health of children and their psychological well-being (Scharf, Mayseless, \& Rousseau, 2016; Uji et al., 2014).

Iglesias and Romero Triñanes (2009) emphasize that the maternal negligent style and paternal authoritarian style have both low scores on the acceptance/implication factor and an association with externalizing behavior in common (Rankin Williams et al., 2009). Respect for parental authority is of paramount importance to families, this fundamental value was defined by Livas-Dlott et al. (2010) as affiliative obedience. Stein and Polo (2014) found that when there is greater discrepancy in affiliative obedience, children are more likely to report more depressive and maladjustment symptoms. Based on all of the above, the aim of this study was to increase the knowledge about the role of which parental educa- 
tional styles are associated with externalizing, internalizing, and adjustment problems in Colombian children.

\section{METHOD}

\section{Study design}

Cross-sectional in paper-based survey.

\section{Participants}

The sample was selected under a probabilistic procedure using simple random sampling with a confidence level of $95 \%$. The inclusion criteria were: 1 . parents over 18 year of age, 2 . parents with a minimum educational level of five of primary school, 3. children between 8 and 12 years old, 4. parental informed consent, and 5. informed assent of children.

The exclusion and modification criteria were: 1. parents under 18 years of age, 2. parents with an educational level below five of primary school, 3 . children under 8 years and over 12 years, 4. lack of informed consent of parents, and 5. lack of informed consent or assent from parents and children.

The elimination criteria were: 1. incomplete instruments answered and 2. voluntary withdrawal of parents or children.

\section{Instruments}

Parent Educational Styles Assessment Questionnaire (PESQ). It allows for the evaluation of parental styles that can be constituted as factors of protection or risk or in the development of psychological problems in children between 6 and 12 years old. The questionnaire is made up of 66 Likert-type items with four response options (1 most often, 2 frequently, 3 sometimes, 4 rarely). It has five scales with corresponding factors that are: Parental practices (promote positive behaviors, dysfunctional reactions to disobedience, inconsistency, proper use of corrections); Educational styles (democratic, permissive, ambiguous, authoritarian); Emotional competences (impulsiveness, emotional expression, recognition of emotions, emotional management); Parental role (parental satisfaction, collaboration with school, parental overload), and Family dynamics (family cohesion, communication, shared leisure, conflicts). The instrument reliability is .92 . Its scales have mean and high reliability scores of .64 and .84 (Gómez et al., 2013).

Child Behavior Checklist (CBCL; Achenbach \& Rescorla, 2001), parent format: allows for evaluating internalizing and externalizing psychological problems in children between 4 and 16 years old. It has a rating as follows: (0) if it is not true, (1) if sometimes it is true and (2) if it is true very often. The direct scores are transformed into
T scores according to the following ranges: clinical: between 64 and 100, borderline: between 60 and 63, normal: between 59 and 33 (Achenbach \& Rescorla, 2001). This instrument has been adapted for the Colombian population where it obtained a reliability coefficient of .83 and an internal consistency of .94 (Hewitt, Jaimes, Vera, \& Villa, 2012).

Self-Assessment Multifactorial Adjustment Test for Children (TAMAI; Hernández-Hernández, 2004). Allows for self-evaluation of personal, social, school, and family non-adjustment scales, in children from 8 to 18 years of age. It has a reliability index $=.87$. It has the following ordinal categories: (very low, 1 to 5 centile); (low; centile of 6 to 20); (almost low, centile 21 to 40), (medium, centile 41 to 60); (almost high, 61 to 80 ); (high, centile 81 to 95); (very high, centile 96 to 99 ).

\section{Procedure}

First, requests to perform the study were sent to the two schools. 750 parents were invited to participate in the study; for this purpose, each school called the parents to a meeting in their facilities. Finally, 422 participated in the study, corresponding to $56.3 \%$. Some did not attend the meetings where the study was presented and others were removed because they did not fully complete the instruments. The parents gave their informed consent to complete the instruments at school, just after explaining the study. To avoid overloading parents with time to complete the instruments, it was verified that they were only answered once based on one of the children included in the study. Subsequently, the objectives of the study were explained to the children and their informed consent was requested to complete the questionnaires in the classroom.

\section{Statistical analysis}

A path analysis was carried out using the AMOS 22 software in which, through structural equations, the fit of the proposed model was verified. We examined whether the hypothetical relationship patterns were consistent with the observed covariance matrix. The fit indexes were those recommended by $\mathrm{Hu}$ and Bentler (1988) for varied samples and different distributions: square chi $\left(\chi^{2}\right.$, cut point $p>.05$ ), goodness index adjustment (AGFI; The comparison adjustment index $(\mathrm{CFI}>.95)$, and the mean squaring error of approximation (RMSEA < .06). Finally, revisions of the change indexes were carried out to determine the best adjusted empirical model.

\section{Ethical Considerations}

The Ethics Committee of the Universidad of Miguel Hernández de Elche approved the study (53245409-H). In order to be granted access to the participants, school princi- 
Table 1

Sociodemographic data of the participants

\begin{tabular}{|c|c|c|}
\hline Parents & Frecuency & Percentage \\
\hline \multicolumn{3}{|l|}{ Age } \\
\hline $18-25$ & 45 & 10.7 \\
\hline $26-33$ & 168 & 39.8 \\
\hline $34-41$ & 118 & 27.9 \\
\hline $42-49$ & 67 & 15.9 \\
\hline $50-57$ & 15 & 3.6 \\
\hline $58-65$ & 9 & 2.1 \\
\hline \multicolumn{3}{|l|}{ Sex } \\
\hline Female & 345 & 81.8 \\
\hline Male & 77 & 18.2 \\
\hline \multicolumn{3}{|l|}{ Civil status } \\
\hline Single & 117 & 27.7 \\
\hline Married & 103 & 24.4 \\
\hline Free union & 168 & 39.8 \\
\hline Separated & 34 & 8.1 \\
\hline \multicolumn{3}{|l|}{ Education level } \\
\hline Complete primary & 49 & 11.7 \\
\hline Incomplete baccalaureate & 37 & 8.8 \\
\hline Complete baccalaureate & 218 & 51.6 \\
\hline Technical & 86 & 20.3 \\
\hline Incomplete university & 22 & 5.1 \\
\hline Complete university & 3 & 0.8 \\
\hline Other & 7 & 1.7 \\
\hline \multicolumn{3}{|l|}{ Occupation } \\
\hline Independent & 144 & 34.2 \\
\hline Employee & 156 & 36.9 \\
\hline Home & 100 & 23.7 \\
\hline Other & 22 & 5.2 \\
\hline \multicolumn{3}{|l|}{ Socioeconomic level } \\
\hline Low 1 & 57 & 13.5 \\
\hline Low 2 & 216 & 51.2 \\
\hline Low 3 & 149 & 35.3 \\
\hline Children & Frecuency & Percentage \\
\hline \multicolumn{3}{|l|}{ Age } \\
\hline 8 & 68 & 16.1 \\
\hline 9 & 112 & 26.6 \\
\hline 10 & 121 & 28.7 \\
\hline 11 & 96 & 22.7 \\
\hline 12 & 25 & 5.9 \\
\hline \multicolumn{3}{|l|}{ Sex } \\
\hline Female & 220 & 52.1 \\
\hline Male & 202 & 47.9 \\
\hline \multicolumn{3}{|l|}{ Education level } \\
\hline 3 & 98 & 23.3 \\
\hline 4 & 131 & 31.1 \\
\hline 5 & 111 & 26.2 \\
\hline 6 & 43 & 10.1 \\
\hline 7 & 22 & 5.2 \\
\hline 8 & 17 & 4.1 \\
\hline Total & 422 & 100 \\
\hline
\end{tabular}

Table 2

Descriptives of parenting styles, externalizing, internalizing and adjustment problems

\begin{tabular}{|c|c|c|c|}
\hline \multicolumn{2}{|c|}{ Variable $(n=422)$} & \multirow{2}{*}{$\frac{M}{8.30}$} & \multirow{2}{*}{$\frac{(S D)}{2.41}$} \\
\hline \multirow{24}{*}{$\begin{array}{l}\text { O } \\
\text { ய } \\
\square\end{array}$} & Family cohesion & & \\
\hline & Communication & 9.42 & 2.41 \\
\hline & Shared leisure & 5.71 & 1.88 \\
\hline & Parental conflicts & 1.43 & 1.43 \\
\hline & Family dynamics & 24.86 & 5.15 \\
\hline & Parental satisfaction & 9.51 & 2.19 \\
\hline & Collaboration with school & 5.43 & 2.18 \\
\hline & Parental overload & 3.55 & 2.35 \\
\hline & Parental role & 18.5 & 4.16 \\
\hline & Impulsiveness & 2.23 & 1.97 \\
\hline & Emotional expression & 7.18 & 1.66 \\
\hline & Recognition of emotions & 6.13 & 1.77 \\
\hline & Emotional management & 2.30 & 1.60 \\
\hline & Emotional competences & 17.85 & 3.45 \\
\hline & Democratic & 7.59 & 1.69 \\
\hline & Permissive & 4.86 & 2.83 \\
\hline & Ambiguous & 5.30 & 1.20 \\
\hline & Authoritarian & 4.32 & 1.29 \\
\hline & Educational styles & 22.1 & 3.18 \\
\hline & Promote positive behaviors & 9.35 & 2.59 \\
\hline & Dysfunctional reactions to disobedience & 4.05 & 2.76 \\
\hline & Inconsistency & 2.73 & 2.20 \\
\hline & Proper use of corrections & 6.37 & 3.08 \\
\hline & Parental practices & 22.50 & 7.14 \\
\hline \multirow{7}{*}{ 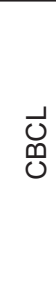 } & Anxious-depressive & 4.60 & 3.74 \\
\hline & Isolated-depressive & 4.37 & 3.69 \\
\hline & Somatic complaints & 3.06 & 2.93 \\
\hline & Internalizing Behavior & 12.03 & 7.94 \\
\hline & Rule breaking & 2.72 & 2.87 \\
\hline & Aggressive behavior & 7.32 & 5.52 \\
\hline & Externalizing behavior & 10.04 & 7.90 \\
\hline \multirow{5}{*}{$\sum_{\mathbb{1}}$} & Personal maladjustment & 9.37 & 5.54 \\
\hline & School maladjustment & 6.10 & 5.46 \\
\hline & Social maladjustment & 8.85 & 5.30 \\
\hline & Family dissatisfaction & 1.21 & 1.29 \\
\hline & General maladjustment & 25.43 & 13.05 \\
\hline
\end{tabular}

pals were asked to provide authorization beforehand. Study objectives were then explained to parents with the purpose of obtaining a signed informed consent to complete the instruments. These steps were taken in accordance to the Helsinki Declaration. Also, the confidentiality on the identity of the participants was provided to comply with ethical considerations.

All procedures performed in studies involving human participants were in accordance with the ethical standards of the institutional and/or national research committee and with the 1964 Helsinki declaration and its later amendments or comparable ethical standards. 
Table 3

Adjustment indexes of models of parental educational styles for the prediction of internalizing, externalizing and adjustment problems

\begin{tabular}{lcccccccc}
\hline Model & $X^{2}$ & $D F$ & $X^{2} / D F$ & $C F I$ & GFI & AGFI & NFI & RMSEA \\
\hline Family dynamics & $94.103^{* * *}$ & 43 & 2.188 & .975 & .967 & .930 & .955 & .053 \\
Parental roles & $76.282^{* * *}$ & 36 & 2.119 & .976 & .971 & .937 & .957 & .052 \\
Emotional competencies & $77.674^{* *}$ & 44 & 1.765 & .981 & .973 & .944 & .958 & .043 \\
Parental educational styles & $70.615^{*}$ & 46 & 1.535 & .986 & .976 & .952 & .961 & .036 \\
Parenting practices & $68.036^{* *}$ & 38 & 1.790 & .985 & .976 & .943 & .967 & .043 \\
\hline
\end{tabular}

Note: $X^{2}$ (Chi square); DF (degrees of freedom); $X^{2} / D F$ (Chi square on degrees of freedom); CFI (Comparative Adjustment Index); GFI (Goodness of fit index); AGFI (Adjusted goodness of fit index); NFI (Normalized Adjustment Index); RMSEA (Root of the Average Squared Error of Approximation).

Source: own elaboration.

${ }^{* * *} p<.001 ;{ }^{* *} p<.01 ;{ }^{*} p<.05$

\section{RESULTS}

The participants were 422 parents and 422 children $(52.1 \%$ girls) with an age range from 8 to 12 years $(\mathrm{M}=9.71 ; S D=$ 1.2 ), of which $31.1 \%$ were in fourth grade in public schools in the city of Bogotá. $81.8 \%$ were mothers and $18.2 \%$ were parents. $39.8 \%$ were in free union, $27.7 \%$ were single, and $24.4 \%$ were married. $29.6 \%$ of the parents were employed; while only $7.3 \%$ of the mothers were employed (Table 1 ).

In Table 2 it can be observed that in the PESQ the parents reported greater use of communication $(M=9.42)$ and the promotion of positive behaviors $(\mathrm{M}=9.35)$ in parenting. They also reported more aggressive behavior in their children $(M=7.32)$, while in children more problems of personal adjustment were found $(M=9.37)$.

As shown in Table 3, the adjustment indicators were favorable for the five established models, since the comparative adjustment index (CFI), goodness of fit index (GFI), adjusted goodness of fit index (AGFI) and the normalized adjustment index (NFI) were above 90 indicating a good fit, and the root of the average squared error of approximation (RMSEA) was below .08.

According to Figure 1, family cohesion, communication, shared leisure, and parental conflicts have a direct effect on anxious-depressive behavior in children. Communication and conflict show a direct relation to the isolated-depressive variable. Communication has a direct effect on the rule breaking behavior. There is an indirect effect of communication problems and family conflicts through aggressive behavior on school and social maladjustment of children.

According to Figure 2, parental overload shows direct effects on anxious-depressive, isolated-depressive, somatic complaints, rule breaking, and family dissatisfaction. In turn, it shows indirect effects on school and social maladjustment through aggressive behavior. Parental satisfaction directly influences the breaking of rules and indirectly on school and social maladjustment through aggressive behavior. Parent collaboration with the school has a direct influence on school maladjustment of their children.
In Figure 3, impulsiveness has direct influences on anxious-depressive, isolated-depressive, somatic complaints, rule breaking, aggressive behavior, school, and social maladjustment. Emotional expression directly explains the isolated depressive problem and the breaking of rules, and indirectly influences school and social maladjustment through aggressive behavior. Emotional recognition and handling co-vary with impulsiveness and emotional expression without direct effect on internalizing, externalizing, and adjustment problems.

According to Figure 4, the democratic parental style directly influences rule-breaking, while the permissive style has direct influences on anxious-depressive, isolated-depressive, somatic complaints, rule breaking, and family dissatisfaction; On the other hand, it also shows indirect influences on school and social maladjustment through aggressive behavior. Ambiguous style denotes a direct influence on family dissatisfaction. Recognition and emotional management co-varied with impulsiveness and emotional expression without direct effects on internalizing, externalizing, and adjustment problems.

As shown in Figure 5, promoting positive behaviors explains directly the anxious-depressive, isolated-depressive, and somatic complaints. It also has indirect influences on school and social maladjustment through rule breaking and aggressive behavior. The dysfunctional reaction of parents to the disobedience of their children evidences a direct influence on the anxious-depressive, isolated-depressive, and somatic complaints, rule breaking and aggressive behavior, as well as on personal, school, and social maladjustment, and family dissatisfaction. The correct use of corrections covariate with the promotion of positive behaviors, dysfunctional reaction to disobedience and inconsistency without direct effects on internalizing, externalizing and adjustment problems.

\section{DISCUSSION AND CONCLUSION}

The present study allowed to increase the knowledge about the role of which parental educational styles are associated 


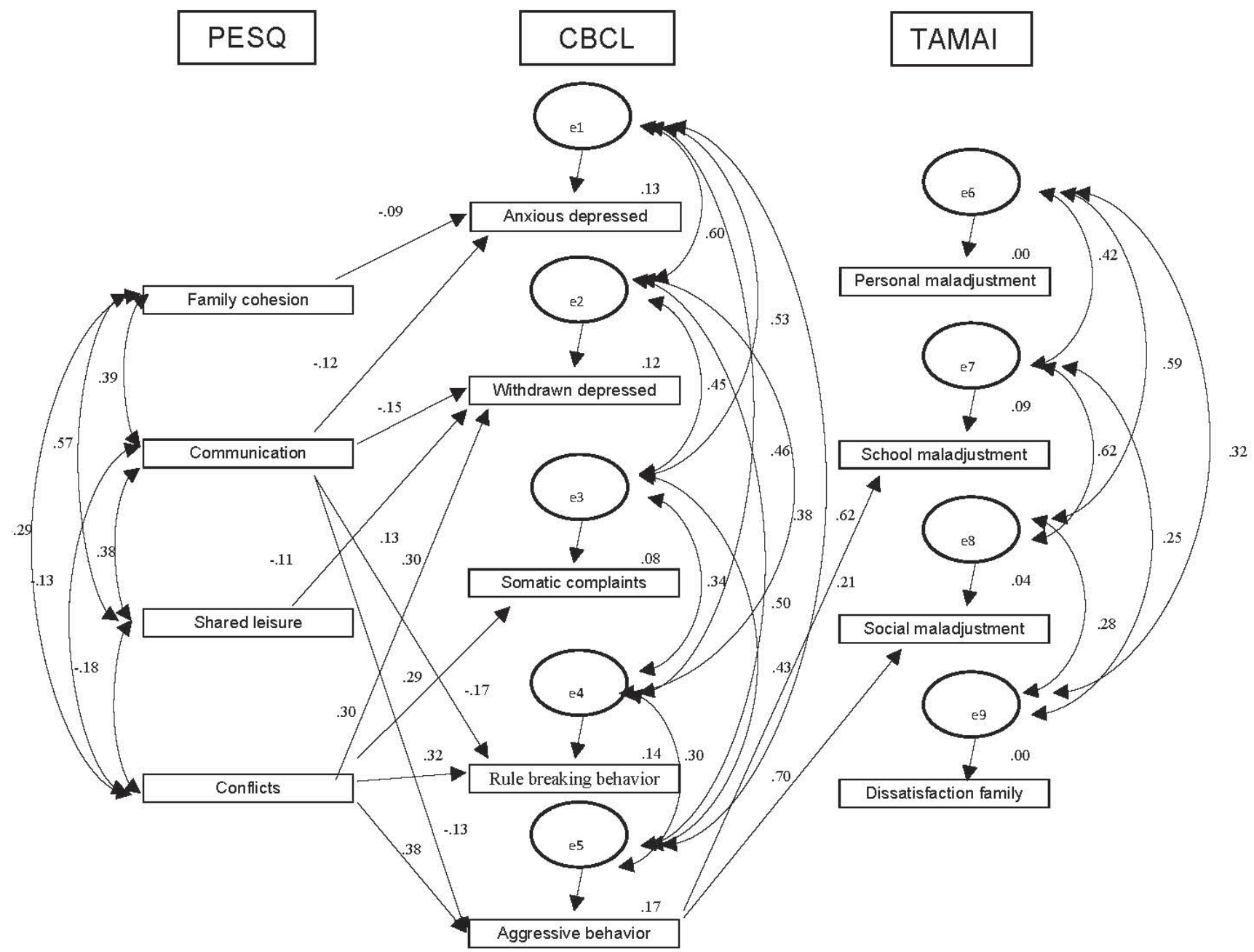

Figure 1. Model of structural equations of subscales of (PESQ) family dynamics predicting (CBCL) internalizing, externalizing and (TAMAI) adjustment problems $\left(\mathrm{e}=\right.$ error; $\left.{ }^{* * *} p<.001\right)$.

with internalizing, externalizing, and adjustment problems in Colombian children. Five tested models show that conflicts at home, parental overload, impulsivity, permissive, ambiguous/non-consistent styles, and dysfunctional reaction to disobedience play a role in the manifestation of internalizing, externalizing, and adjustment problems in children. Contrary to the above, family cohesion, communication, shared leisure, parental satisfaction, collaboration with school, recognition, emotional management, and expression, democratic style, and the promotion of positive behaviors emerge as protective factors for psychological and adjustment problems.

The results found that difficulties in family cohesion, communication, shared leisure, and conflict play an important role in internalizing problems. This is in line with the findings of Cumsille et al. (2015) who state that, when children perceive little affection and insecurity, they show anxiety and depression. In turn, Verdugo et al. (2014) report that, the greater the family cohesion, is the better ad- justment in the children is. Baker (2014) and Offer (2014) emphasize that for children it is beneficial for their school adjustment to have shared time with their parents because they experience high positive affection, something fundamental for positive parenting.

It is striking that most children live in non-traditional homes characterized by parents who have a free union and single-parent homes. This could have an impact on the upbringing of the children, since the parents would have fewer opportunities for dedication of the children and as a consequence the manifestation of adaptation problems in the children (Chisholm et al., 2014; Muratori et al., 2016).

Communication and conflict also have a link with externalizing problems and school and social maladjustment. Jouriles et al. (2014) and Zuñeda et al. (2016) found that children with communication problems in the family ended up having aggressiveness and difficulties in adapting to life events.

Parental overload also shows effects on internalizing and externalizing problems and on school and social mal- 

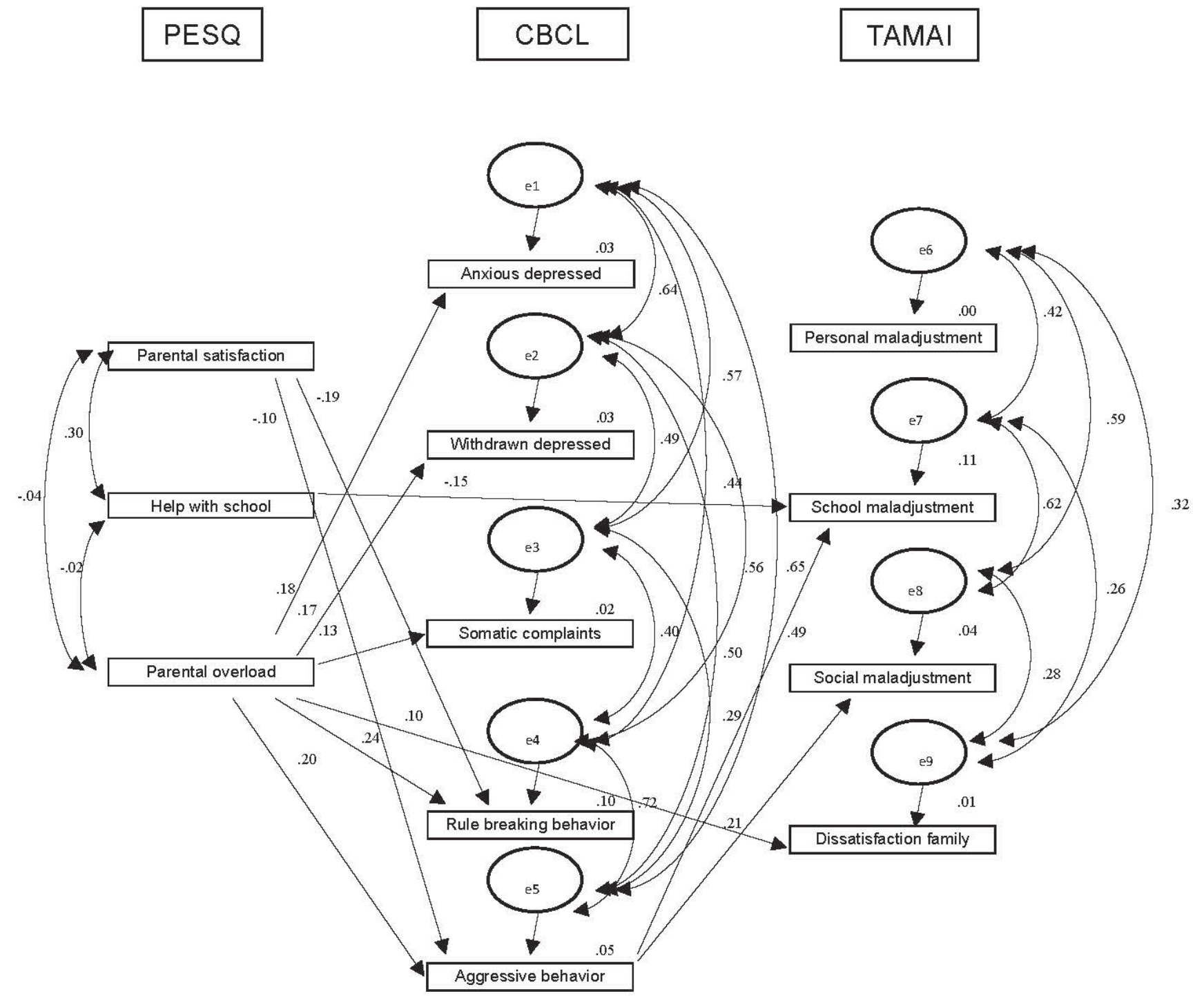

Figure 2. Model of structural equations of subscales of (PESQ) parental role predicting (CBCL) internalizing, externalizing and (TAMAI) adjustment problems $\left(\mathrm{e}=\right.$ error; $\left.{ }^{* * *} p<.001\right)$.

adjustment, since the lack of parental involvement and support in child nurturing makes it difficult to develop prosocial skills and self-regulation in children, which in turn leads them to show problems of sub-controlled or hyper-controlled behavior and difficulties to respond to the demands of school and social environment (Chisholm et al., 2014; Murry et al. 2014; Muratori et al., 2016; Raya et al., 2009).

On the other hand, the role of parental satisfaction and collaboration with school on behavioral problems and school maladjustment can explain why, when parents feel satisfied with their children's education, they are more willing to set limits and consistent standards, which allows children to respect and follow the family rules (Barg, 2019; García-Bacete, 2003).

Regarding the role of parents' impulsivity about externalizing behaviors, Hamilton et al. (2014) and Henschel et al. (2014) report that impulsivity is related to decreased self-control and increased aggression in children. The direct relationship of emotional expression to internalizing problems problems would indicate that the frecuency and valence of positive verbal and nonverbal emoticional expressions of parents towards their children is low can be explained according to what (Bariola et al., 2011), when parents have cold attitudes and disregard their children's emotions, they hinder their emotional development and socialization processes (Mirabile, 2014; Ramírez-GarcíaLuna et al., 2016).

The democratic or authoritative style directly influences the behavior of breaking rules. This is consistent with what has been found by Jabagchourian et al. (2014), Jiménez-Barbero et al. (2016); Rankin Williams et al. (2009), in the sense that this style is associated with a decrease in externalizing behaviors and follows up of rules, 

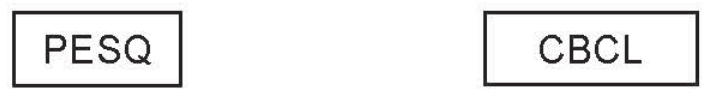

TAMAI

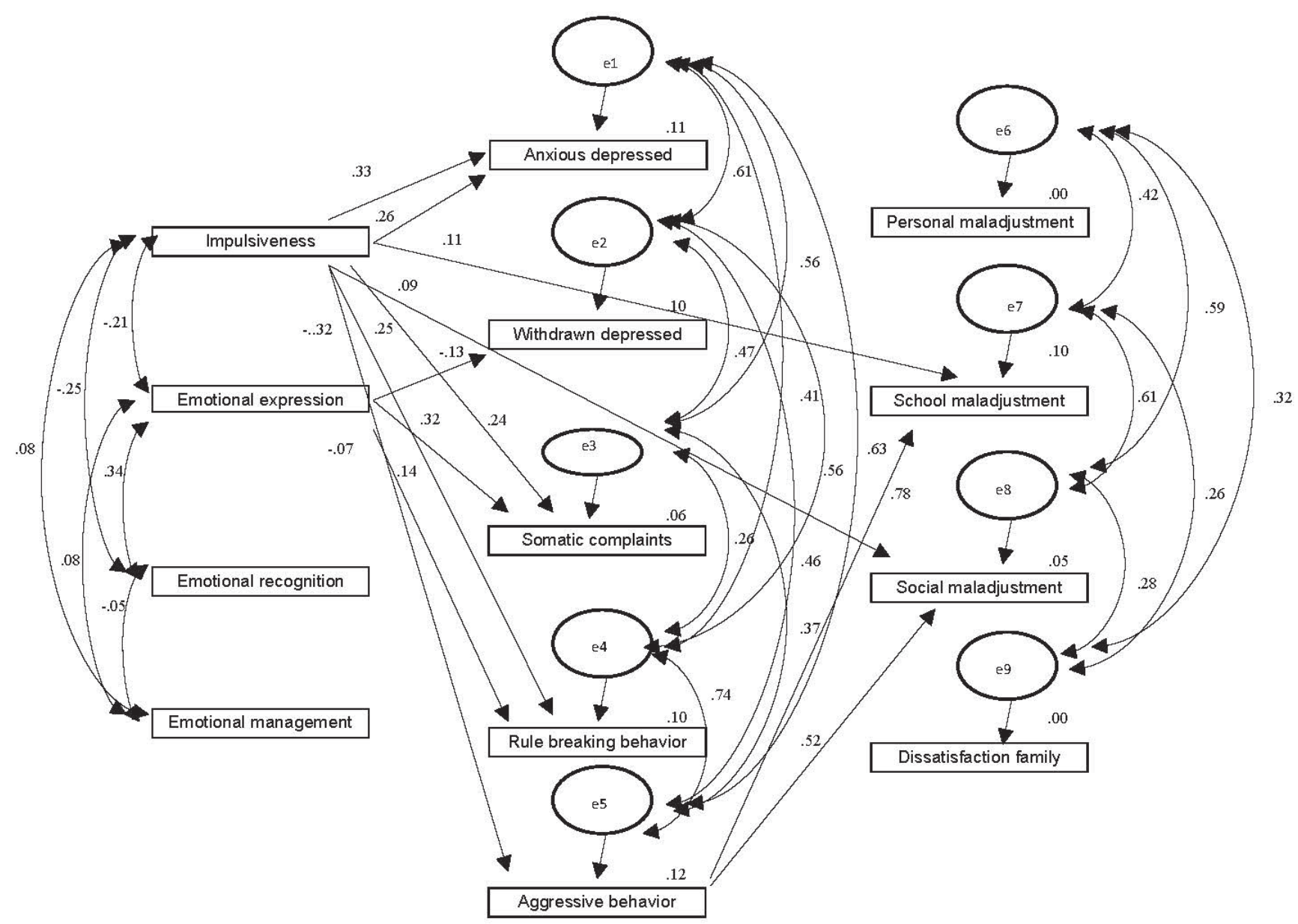

Figure 3. Model of structural equations of subscales of (PESQ) emotional competence predicting (CBCL) internalizing, externalizing and (TAMAI) adjustment problems $\left(\mathrm{e}=\right.$ error; $\left.{ }^{* * *} p<.01\right)$.

since when parents are affectively warm, they use reasoning and promote autonomy, they can strengthen emotional security and the manifestation of adjustment behavior in their children. It also has a beneficial impact on children's mental health and education (Osorio \& González-Cámara, 2016; Uji et al., 2014) and the development of socially accepted behaviors.

A permissive parental style has direct influences on internalizing problems. It has been associated with such problems, especially in children who have behavioral inhibition patterns (Rankin Williams et al., 2009). It also shows indirect effects on school and social maladjustment through aggressive behavior. This is consistent with the findings of Moreno et al. (2014) and Babinski, Waschbusch, King, Joyce, and Andrade (2017) because the permissive style affects the adjustment and the school performance of chil- dren. It also has an impact on their mental health (Barton \& Hirsch, 2016; Uji et al., 2014).

An ambiguous/inconsistent style denotes a direct influence on family dissatisfaction. This may be because ambiguity generates confusion and uncertainty and frustration in children. On the other hand, consistency in parenting favors the development of high levels of self-control and family satisfaction (Berkien, Louwerse, Verhulst, \& Van der Ende, 2012). Iglesias and Romero Triñanes (2009) found that the permissive parenting style of mothers combined with the authoritarian parenting style were associated with externalizing child problems and depression. The common element is that they are ineffective styles, because the predominant use of any of these dimensions maintains an inconsistent raising style (Laukkanen et al., 2014). 

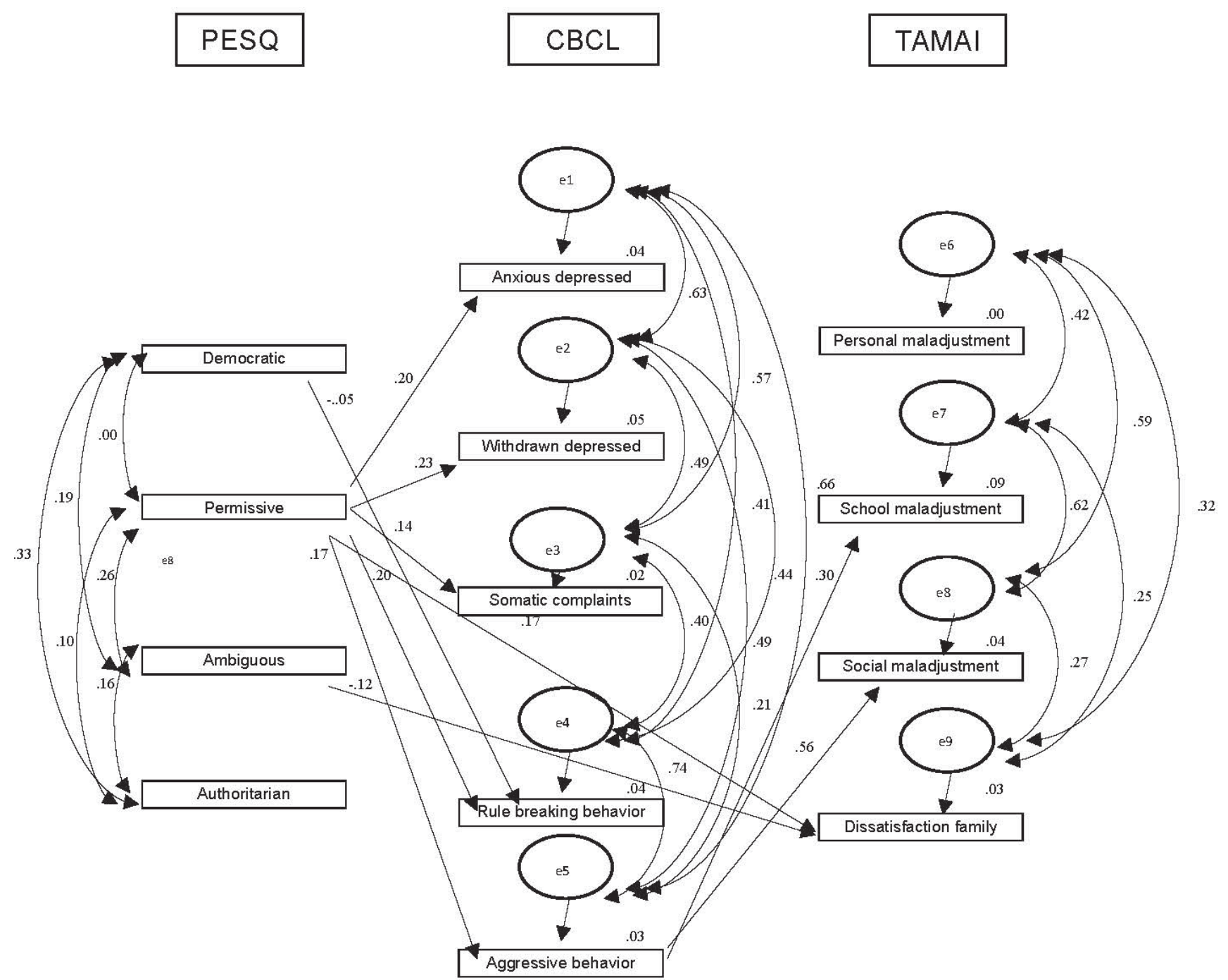

Figure 4. Model of structural equations of subscales of (PESQ) parental styles predicting (CBCL) internalizing, externalizing and (TAMAI) adjustment problems $\left(\mathrm{e}=\right.$ error; $\left.{ }^{* * *} p<.05\right)$.

The promotion of positive behaviors and the dysfunctional reaction to disobedience show an inverse relationship with the internalizing and externalizing problems with the consequent problems of school and social maladjustment and family dissatisfaction. According to Barry et al. (2008), positive parenting perceived in children has an inverse relationship with depression in them. Berkien et al. (2012) have found a relationship between negative parenting patterns and symptoms of anxiety and depression. These symptoms in turn interfere with school and social adjustment (Voltas et al., 2016).

The infrequent use of positive parenting practices may be associated with a lack of affiliation with parental values, and possibly with links to other aspects of the community, such as a child will be more likely to engage in activities (Barry et al., 2008) and to report higher levels of depressive symptoms and maladjustment (Stein \& Polo, 2014).
The results of the present study have important implications for mental health, because they provide information based on the evidence of instruments such as PESQ, CBCL, and TAMAI that can be used in clinical evaluations to understand the relationships between parental styles and adaptation problems in children, even though it was a school based sample.

At the school and community level, the study suggests information to strengthen the schools parents programs, and prevention and promotion strategies that include communication skills, conflict resolution, emotional regulation, and general guidelines for parents. These aspects help to prevent the problems of adaptation of children in the family, school, and social environment.

Limitations of the present study are that it was carried out in school settings and no comparison was made with a clinical sample, nor was the evaluation of teachers, which is a gap to be filled for future research. 


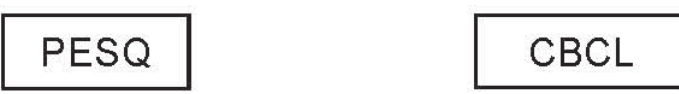

TAMAI

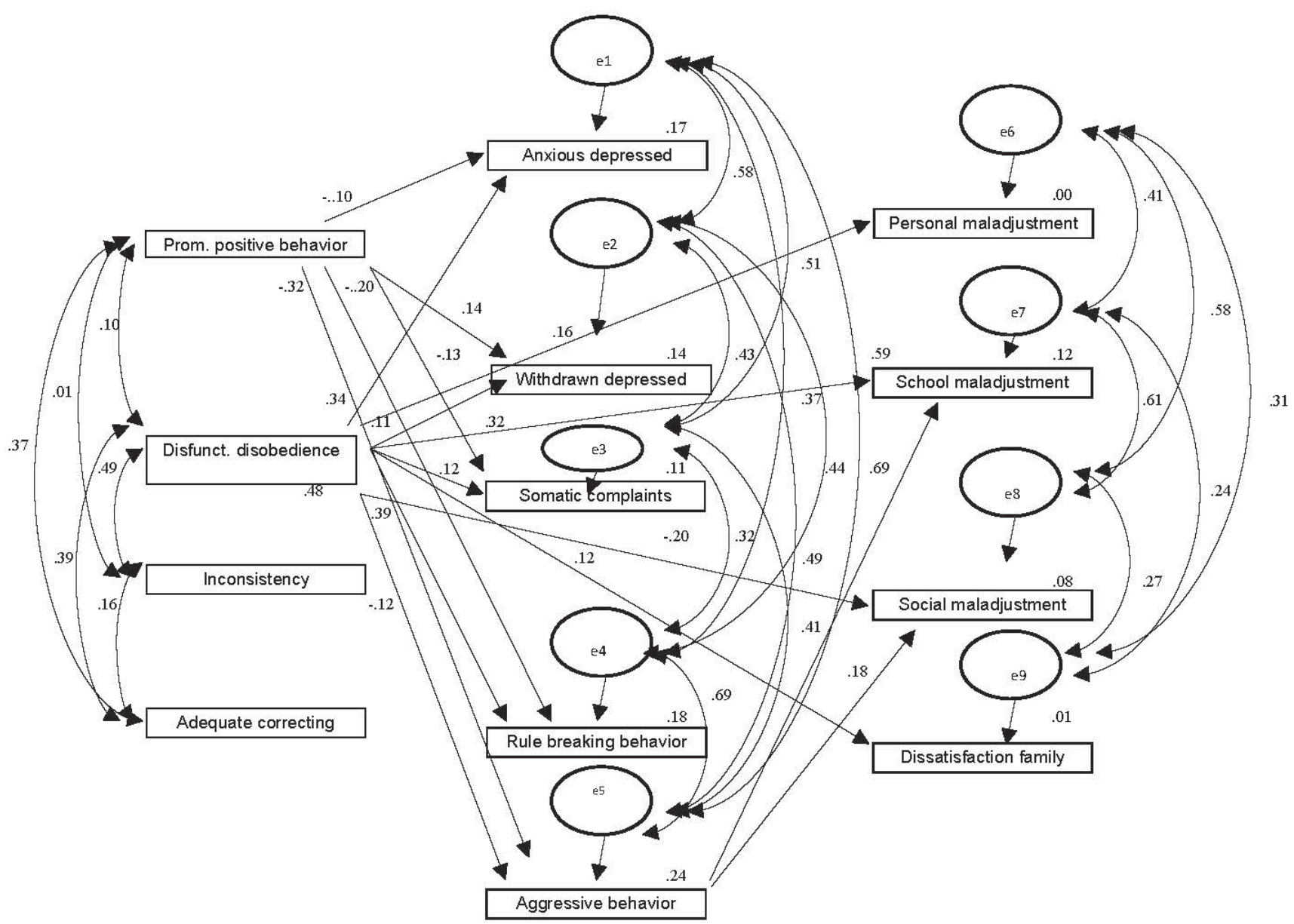

Figure 5. Model of structural equations of subscales of (PESQ) parental practices predicting (CBCL) internalizing, externalizing and (TAMAI) adjustment problems $\left(\mathrm{e}=\right.$ error; $\left.{ }^{* *} p<.01\right)$.

It can be said that most results were obtained from the evaluation done by the mothers rather than fathers, since in the Colombian context it is more difficult to observe it is more difficult to access the sample of the male parent, in this sense it is suggested for future investigations to include a homogeneous sample in this regard.

It was not possible to clearly identify the role of authoritarian parental style in externalizing, internalizing, and adjustment problems, which requires further deepening. Likewise, the results only allow for correlations and associations to be presented, which makes it impossible to establish causal relationships of the parents' styles on the behavior of the children, so it would be necessary to conduct quasi-experimental and longitudinal studies that allow us to account for it.

\section{Funding}

The research was funded by the authors of the study.

\section{Conflicts of interest}

The authors declare they have no conflicts of interest.

\section{REFERENCES}

Achenbach, T. M., \& Rescorla, L. A. (2001). Manual for the ASEBA school-age forms and profiles. Burlington, VT: University of Vermont, Research.

Babinski, D. E., Waschbusch, D. A., King, S., Joyce, A. M., \& Andrade, B. F. (2017). Maternal and paternal parenting and associations with school performance in a sample of children with varying levels of externalizing behavior problems. School Mental Health, 9(4), 322-333. doi: 10.1007/s12310-017-9229-0

Baker, C. E. (2014). African American fathers' contributions to children's early academic achievement: Evidence from two-parent families from the early childhood longitudinal study-birth cohort. Early Education and Development, 25(1), 19-35. doi: 10.1080/10409289.2013.764225 
Barg, K. (2019). Why are middle-class parents more involved in school than workingclass parents? Research in Social Stratification and Mobility, 59, 14-24. doi: 10.1016/j.rssm.2018.12.002

Bariola, E., Gullone, E., \& Hughes, E. K. (2011). Child and adolescent emotion regulation: The role of parental emotion regulation and expression. Clinical Child and Family Psychology Review, 14(2), 198-212. doi: 10.1007/s10567-011-0092-5

Barry, C. T., Frick, P. J., \& Grafeman, S. J. (2008). Child versus parent reports of parenting practices: implications for the conceptualization of child behavioral and emotional problems. Assessment, 15(3), 294-303. doi: 10.1177/1073191107312212

Barton, A. L., \& Hirsch, J. K. (2016). Permissive parenting and mental health in college students: Mediating effects of academic entitlement. Journal of American College Health, 64(1), 1-8. doi: 10.1080/07448481.2015.1060597

Berkien, M., Louwerse, A., Verhulst, F., \& Van der Ende, J. (2012). Children's perceptions of dissimilarity in parenting styles are associated with internalizing and externalizing behavior. European Child and Adolescent Psychiatry, 21(2), 79-85. doi: 10.1007/s00787-011-0234-9

Chen, F. R., Raine, A., Rudo-Hutt, A. S., Glenn, A. L., Soyfer, L., \& Granger, D. A. (2015). Harsh discipline and behavior problems: The moderating effects of cortisol and alpha-amylase. Biological Psychology, 104, 19-27. doi: 10.1016/j. biopsycho.2014.11.005

Chisholm, V., Gonzalez, A., \& Atkinson, L. (2014). Interpersonal engagement mediates the relation between maternal affect and externalizing behavior in young children with type 1 diabetes. PLoS One, 9(6), e97672. doi: 10.1371/ journal.pone.0097672

Cumsille, P., Martínez, M. L., Rodríguez, V., \& Darling, N. (2015). Parental and individual predictors of trajectories of depressive symptoms in Chilean adolescents. International Journal of Clinical and Health Psychology, 15(3), 208-216. doi: 10.1016/j.ijchp.2015.06.001

García-Bacete, F. J. (2003). Las relaciones escuela-familia: un reto educativo. Infancia y Aprendizaje, 26(4), 425-437. doi: 10.1174/021037003322553824

Gómez, I., García-Barranco, M. R., De las Heras, R. R., Martínez de Salazar, A. A., Cobos, L. S., Martin, M. J. G., \& Fernández, C. S. (2013). Memoria del proyecto investigación: Evaluación de Estilos Educativos Parentales. Patrocinado por la Asociación Española de Psicología Clínica y Psicopatología (AEPCP). Retrieved from http://www.aepcp.net/arc/Memoria\%20\%20final\%20 Ayuda $\% 20$ Investigacio\%CC $\% 81$ n $\% 20 \% 20$ AEPCP $\% 20(2011)$.pdf

Hamilton, K. R., Sinha, R., \& Potenza, M. N. (2014). Self-reported impulsivity, but not behavioral approach or inhibition, mediates the relationship between stress and self-control. Addictive Behaviors, 39(11), 1557-1564. doi: 10.1016/j. addbeh.2014.01.003

Henschel, S., de Bruin, M., \& Möhler, E. (2014). Self-Control and child abuse potential in mothers with an abuse history and their preschool children. Journal of Child and Family Studies, 23(5), 824-836. doi: 10.1007/s10826-013-9735-0

Hernández-Hernández, P. (2004). TAMAI: Test Autoevaluativo Multifactorial de Adaptación Infantil: Manual. Madrid: TEA Ediciones S.A.

Hernández, L. M., Gómez, B. I., Martin, G. M. J., \& González, G. C. (2008). Prevención de la violencia infantil-juvenil: estilos educativos de las familias con factores de protección. International Journal of Psychology and Psychological Therapy, 8(1), 73-84. Retrieved from http:/www.ijpsy.com/volumen8/ num1/185/prevencin-de-la-violencia-infantil-juvenil-ES.pdf

Hewitt, N., Jaimes, S., Vera., L. A., \& Villa, M. C. (2012). Psychometric features of the children's behavior questionnaires for Colombian Children and Adolescents (CBCL). (Unpublished thesis). Facultad de Psicología. Universidad de San Buenaventura. Bogotá - Colombia.

Hser, Y., Lanza, H. I., Li, L., Kahn, E., Evans, E., \& Schulte, M. (2015). Maternal mental health and children's internalizing and externalizing behaviors: beyond maternal substance use disorders. Journal of Child and Family Studies, 24(3), 638-648. doi: 10.1007/s10826-013-9874-3

Hu, L., \& Bentler, P. M. (1988). Fit indices in covariance structure modeling: Sensitivity to under parameterized model misspecification. Psychological Methods, 3(4), 424-453. doi: 10.1037/1082-989X.3.4.424

Iglesias, B., \& Romero Triñanes, E. (2009). Estilos parentales percibidos, psicopatología y personalidad en la adolescencia. Revista de Psicopatología y Psicología Clínica, 14(2), 63-77. doi: 10.5944/rppc.vol.14.num.2.2009.4067
Jabagchourian, J. J., Sorkhabi, N., Quach, W., \& Strage, A. (2014). Parenting styles and practices of Latino parents and Latino fifth graders' academic, cognitive, social, and behavioral outcomes. Hispanic Journal of Behavioral Sciences, 36(2), 175-192. doi: 10.1177/0739986314523289

Jiménez-Barbero, J. A., Ruiz-Hernández, J. A., Velandrino-Nicolás, A. P., \& LlorZaragoza, L. (2016). Actitudes hacia la violencia, impulsividad, estilos parentales y conducta externalizada en adolescentes: comparación entre una muestra de población general y una muestra clínica. Anales de Psicología, 32(1) 132-138. doi: 10.6018/analesps.32.1.195091

Jouriles, E. N., Rosenfield, D., McDonald, R., \& Mueller, V. (2014). Child involvement in interparental conflict and child adjustment problems: A longitudinal study of violent families. Journal of Abnormal Child Psychology, 42(5), 693-704. doi: 10.1007/s10802-013-9821-1

Laukkanen, J., Ojansuu, U., Tolvanen, A., Alatupa, S., \& Aunola, K. (2014). Child's difficult temperament and mothers' parenting styles. Journal of Child and Family Studies, 23(2), 312-323. doi: 10.1007/s10826-013-9747-9

Leathers, S. J., Spielfogel, J. E., Geiger, J., Barnett, J., \& Voort, B. L. V. (2019). Placement disruption in foster care: Children's behavior, foster parent support, and parenting experiences. Child Abuse \& Neglect, 91, 147-159. doi: 10.1016/j. chiabu.2019.03.012

Leiner, M., Villanos, M. T., Puertas, H., Peinado, J., Ávila, C., \& Dwivedi, A. (2015). The emotional and behavioral problems of children exposed to poverty and/ or collective violence in communities at the Mexico-United States border: A comparative study. Salud Mental, 38(2), 95-102. doi: 10.17711/SM.01853325.2015 .013

Livas-Dlott, A., Fuller, B., Stein, G. L., Bridges, M., Mangual Figueroa, A., \& Mireles, L. (2010). Commands, competence, and cariño: Maternal socialization practices in Mexican American. families. Developmental Psychology, 46(3), 566-578. doi: 10.1037/a0018016

McCullough, C., \& Shaffer. A. (2014). Maternal depressive symptoms and child externalizing problems: moderating effects of emotionally maltreating parenting behaviors. Journal of Child and Family Studies, 23(2), 389-398. doi: 10.1007/ s10826-013-9804-4

Ministerio de Salud \& Colciencias (2015). Encuesta Nacional de Salud Mental. Colombia. Retrieved from http://www.odc.gov.co/Portals/1/publicaciones/pdf/ consumo/estudios/nacionales/CO031102015-salud_mental_tomoI.pdf

Mirabile, S. P. (2014). Parents' inconsistent emotion socialization and children's socioemotional adjustment. Journal of Applied Developmental Psychology, 35(5), 392-400. doi: 10.1016/j.appdev.2014.06.003

Moreno, J. H. M., Echavarría, K., Pardo, A., \& Quiñones, Y. (2014). Funcionalidad familiar, conductas internalizadas y rendimiento académico en un grupo de adolescentes de la ciudad de Bogotá. Psychologia: Avances de la Disciplina, 8(2), 37-46. doi: 10.21500/19002386.1220

Muratori, P., Lochman, J. E., Manfredi, A., Milone, A., Nocentini, A., Pisano, S., \& Masi, G. (2016). Callous unemotional traits in children with disruptive behavior disorder: Predictors of developmental trajectories and adolescent outcomes. Psychiatry Research, 236, 35-41. doi: 10.1016/j.psychres.2016.01.003

Murry, V. M, McNair, L. D., Myers, S. S., Chen, Y. F., \& Brody, G. H. (2014). Intervention induced changes in perceptions of parenting and risk opportunities among rural African American. Journal of Child and Family Studies, 23(2), 422-436. doi: 10.1007/s10826-013-9714-5

Offer, S. (2014). Time with children and employed parents' emotional well-being. Social Science Research, 47, 192-203. doi: 10.1016/j.ssresearch.2014.05.003

Osorio, A., \& González-Cámara, M. (2016). Testing the alleged superiority of the indulgent parenting style among Spanish adolescents. Psicothema, 28(4), 414420. doi: $10.7334 /$ psicothema2015.314

Pearl, A. M., French, B. F., Dumas, J. E., Moreland, A. D., \& Prinz, R. (2014). Bidirectional effects of parenting quality and child externalizing behavior in predominantly single parent, under-resourced African American families. Journal of Child and Family Studies, 23(2), 177-188. doi: 10.1007/s10826-0129692-Z

Porche, M. V., Costello, D. M., \& Rosen-Reynoso, M. (2016). Adverse family experiences, child mental health, and educational outcomes for a national sample of students. School Mental Health, 8(1), 44-60. doi: 10.1007/s12310$016-9174-3$ 
Ramírez-GarcíaLuna, J. L., Araiza-Alba, P., Martínez-Aguiñaga, S. G., RojasCalderón, H., \& Pérez-Betancourt, M. M. (2016). Correlation and agreement between depressive symptoms in children and their parent's perception. Salud Mental, 39(5), 243-248. doi: 10.17711/SM.0185-3325.2016.028

Rankin Williams, L., Degnan, K. A., Perez-Edgar, K. E., Henderson, H. A., Rubin, K. H., Pine, D. S., ... Fox, N. A. (2009). Impact of behavioral inhibition and parenting style on internalizing and externalizing problems from early childhood through adolescence. Journal of Abnormal Child Psychology, 37(8), 1063-1075. doi:10.1007/s10802-009-9331-3

Raya, A. F., Pino, M. J., \& Herruzo, J. (2009). La agresividad en la infancia: el estilo de crianza parental como factor relacionado. European Journal of Education and Psychology, 2(3), 211-222. Retrieved from http://www.redalyc.org/articulo. oa? id=129312574004

Rescorla, L. A., Althoff, R. R., lvanova, M. Y., \& Achenbach, T. M. (2019). Effects of society and culture on parents' ratings of children's mental health problems in 45 societies. European Child \& Adolescent Psychiatry, 28(8), 1107-1105. doi: 10.1007 /s00787-018-01268-3

Scharf, M., Mayseless, O., \& Rousseau, S. (2016). When somatization is not the only thing you suffer from: Examining comorbid syndromes using latent profile analysis, parenting practices and adolescent functioning. Psychiatry Research, 244, 10-18. doi: 10.1016/j.psychres.2016.07.015

Stein, G. L., \& Polo, A. J. (2014). Parent-Child cultural value gaps and depressive symptoms among Mexican American youth. Journal of Child and Family Studies, 23(2), 189-199. doi: 10.1007/s10826-013-9724-3
Stoltz, S., Van Londen, M., Deković, M., Prinzie, P., de Castro, B., \& Lochman, J. E. (2013). Simultaneously testing parenting and social cognitions in children at-risk for aggressive behavior problems: sex differences and ethnic similarities. Journal of Child and Family Studies, 22(7), 922-931. doi: 10.1007/s10826-0129651-8

Uji, M., Sakamoto, A., Adachi, K., \& Kitamura, T. (2014). The impact of authoritative, authoritarian, and permissive parenting styles on children's later mental health in Japan: Focusing on parent and child gender. Journal of Child and Family Studies, 23(2), 293-302. doi: 10.1007/s10826-013-9740-3

Verdugo Lucero, J. C., Arguelles Barajas, J., Guzmán Muñiz, J., Márquez González, C., Montes Delgado, R., \& Uribe Alvarado, I. (2014). Influencia del clima familiar en el proceso de adaptación social del adolescente. Psicología desde El Caribe, 31(2), 207-222. doi: 10.14482/psdc.31.2.6127. Retrieved from https:// www.redalyc.org/pdf/213/21331836002.pdf

Voltas, N., Hernández-Martínez, C., Arija, V., \& Canals, J. (2016). The three-year developmental trajectory of anxiety symptoms in non-clinical early adolescents. Psicothema, 28(3), 284-290. doi: 10.7334/psicothema2015.332

Zuñeda, A., Llamazares, A., Marañón, D., \& Vázquez, G. (2016). Características individuales y familiares de los adolescentes inmersos en violencia filioparental: La agresividad física, la cohesión familiar y el conflicto interparental como variables explicativas. Revista de Psicopatología y Psicología Clínica, 21(1), 21-33. doi: 10.5944/rppc.vol.21.num.1.2016.15021 